\title{
EFFECTIVENESS OF THE USE OF LEARNING MODEL CONTROVERSIAL ISSUES (CI) ON CRITICAL THINKING ABILITY
}

\author{
Edo Dwi Cahyo ${ }^{1)}$, Laila Kodariyati ${ }^{1)}$ \\ ${ }^{1)}$ STKIP PGRI Metro, Lampung, Indonesia \\ Corresponding Author: edodwicahyo@gmail.com
}

\begin{abstract}
This research is motivated by the low ability of students to think critically. The purpose of the study was to determine the effect of the Controversial Issues (CI) learning model in improving students' critical thinking skills. This study uses a quantitative approach with a quasi-experimental method. The study design used Nonequivalent [Pre-Test and Post-Test] Control Groups Design (NCGD). The research samples were fourth grade students of SDN 4 Metro Timur, SDN 5 Metro Timur, SDN 8 Metro Timur, and SDN 10 Metro Timur, 60 students were used as the experimental class and 60 students were used as the control class. Data collection tools in the form of sheets about students' critical thinking skills. Data collection techniques in the form of tests, namely pretest to measure the initial ability of students' critical thinking skills and posttest to see the final ability. Based on the results of the study concluded that the effectiveness of the use of the Controversial Issues learning model affects the critical thinking skills of class IV elementary school students, so that students' critical thinking skills in the experimental class are much better when compared to the control class that has conventional learning.
\end{abstract}

Keywords: Controversial Issues, learning model, Social Skills..

\section{INTRODUCTION}

Critical thinking is the key to learning and understanding science. Through critical thinking students have the autonomy needed to make a decision that makes students more independent, so students can solve problems related to daily life. At the most general level critical thinking is the main skill in the form of knowledge, because it requires good consideration and high reflectivity. As stated by Facione (in Kaddoura, [1]) that critical thinking is a regulatory assessment that results in interpretation, analysis, evaluation, and conclusion. This process provides evidence-based considerations, contexts, conceptualizations, methods, and criteria. Hughes [2] also argues that over the past 2500 years, critical thinking has been established as one of the most important thinking skills in education. Not only is the National Governors Association Center for Best Practices \& Council of Chief State School Officers (in Kettler [3]) states that 46 of the 50 states in the United States are committed to developing students' critical thinking skills at the elementary school level.

Hope with reality is not always balanced because the findings of social studies learning in developing students' critical thinking skills in elementary schools are still not optimal. It is evident from the findings that the learning process conducted so far shows that the teacher is still dominant in the learning process. The opportunity for students to be able to develop the basic abilities of logical and critical thinking is still hampered by learning situations that only contain material delivery. Learning that only explains subject matter makes students less active in the learning process. The accuracy of the application of the model used also influences student activity in learning. Evaluations that are not well targeted and continuous are also suspected to be the cause of difficult development of students' critical thinking skills. In line with these thoughts, Somantri [4] explains that the problems faced in social studies teaching in elementary schools include the poor quality of teacher teaching and learning. In the learning process, teachers tend to convey material verbally (conventional learning) so that it does not train students to think critically. Research conducted by Takidin [5] also explained that social studies learning in elementary schools tended to be more theoretical and seemed to be separate from the real life of students by focusing on how to spend subject matter from textbooks.

Based on these problems, a learning innovation is needed to develop students' critical thinking skills, so that the objectives of social studies learning can be realized. As revealed by Gunawan [6] that through social studies education students are expected to have basic abilities such as logical and critical thinking. Therefore, the researcher intends to test the Controversial Issues (CI) learning model as a learning innovation that is considered appropriate to be used to improve students' critical thinking skills.

Characteristics of critical thinking include the ability to ask various questions, identify problems, solve problems, make decisions, reasoning, and think 
about language skills. These characteristics are an illustration or peculiarity of an ability that is owned by a person, so that if someone has the ability as the characteristics above, it can be characterized that the person has critical thinking. According to Lockwood (in Mulyati [7]) explained that the Controversial Issues learning model is needed to shape the ability to participate in solving problems in a democratic society by means of discussion. Other opinions expressed by Museing (in Komalasari [8]) Controversial Issues learning model is a learning model that presents controversial issues that are easily accepted by a person or group but are also easily rejected by other people or groups. The benefits in the learning model are learning controversial issues important to prevent gaps and misunderstandings, which can lead to conflict. Learning about controversial issues can be used by teachers to develop basic abilities to prevent the development of anarchic attitudes and actions. Learning controversial issues can train students' critical thinking skills, because it allows students different understanding and views on an issue. Differences in views among students, will provide insight and instill awareness of the existence of differences in life, so that in the end will have a democratic attitude in every aspect of life in accordance with the reality of life in a pluralistic society (Suryanto [9]).

The steps to be taken in learning the Controversial Issues learning model are as follows; a). teachers and students brainstorm on controversial issues to be discussed, b). students in groups choose one of the cases to study, c). students do inquiry, invite speakers, read books, collect other information, d) students present or discuss the results of inquiry, submit arguments, listen to couters or other opinions, e). students apply concepts, generalizations, social science theories to academically analyze problems (Komalasari [8]).

The purpose of this research is to; knowing the effectiveness of using the Controversial Issues (CI) learning model on students' critical thinking abilities. Based on the description, the hypothesis in this study are: There are differences in critical thinking skills of students who obtain the Controversial Issues learning model in the experimental class with students who obtain conventional learning in the control class.

\section{RESEARCH METHODS}

In this study using a quantitative approach, Sugiyono [10] explains the quantitative approach is a research approach based on the philosophy of positivism, used to examine certain populations or samples, collecting data using research instruments, analyzing quantitative / statistical data, with the aim of test the predetermined hypothesis.

The method used in this study is the Quasi Experiment method. Quasi-experimental research is a quasi-experimental study in which research subjects are not randomly grouped, but accept the state of the subject as it is (Ruseffendi [11]). The research design using Control Groups Design (NCGD) Nonequivalent [Pre-Test and Post-Test] in this design there are two groups (2 elementary experimental groups and 2 elementary control groups) randomly selected then given a pretest to find out the initial condition is there a difference between experimental group and control group. The experimental group (A) and the control group (B) were selected without the random placement procedure in the two groups, the same was done before the pre-test and post-test only the experimental group was treated (Creswell [12]). So from the two existing research groups, namely the experimental class and the control class were chosen not randomly, but accepted the subject situation as it is. Then the two classes were given pretest and posttest and only the experimental group was treated using the Controversial Issues learning model. While the control class with conventional learning techniques.

Nonequivalent [Pre-Test and Post-Test] Control Groups Design (NCGD) can be described as follows:

Kelompok $\mathrm{A} \mathrm{O}_{1} \longrightarrow \mathrm{X}$
Kelompok B O $\mathrm{O}_{1}$

Information:

\begin{tabular}{|c|c|}
\hline A & Experimental class group \\
\hline $\mathrm{B}$ & Control class group \\
\hline $\mathrm{O}_{1}$ & Pretest \\
\hline $\mathrm{O}_{2}$ & Posttest \\
\hline$X$ & Controversial Issues learning model \\
\hline
\end{tabular}

The location of this study was carried out in elementary schools located in Metro Timur Subdistrict, Metro City, namely SDN 4 Metro Timur, SDN 5 Metro Timur, SDN 8 Metro Timur and SDN 10 Metro Timur. In this study, the study population was all class fourth students who were in the elementary school. The sample of the study were 60th grade students of SDN 4 and SDN 5 Metro Timur as many as 60 students as control classes and students in class IV SDN 8 and SDN 10 Metro Timur as many as 60 students as the experimental class.

The instrument used to obtain the data needed in this study is a test of students' critical thinking skills. The data obtained comes from the test instrument. In order to know the quality of the test equipment that has been prepared, then the test equipment is tested beforehand on students. A good and quality test tool can be seen from several aspects including validity, reliability, level of difficulty, and distinguishing power.

The data generated from this study are quantitative data, the data comes from pretest and posttest data in the experimental class and the control 
class. In this study data analysis techniques used using computer software assistance, namely SPSS version 20 with a statistical approach, among others, namely the normality test, and different tests.

\section{RESULTS AND DISCUSSION}

Based on the results of the scoring obtained data in the form of pretest and posttest values of students' critical thinking abilities. In the experimental class the average value achieved at pretest was 7.83 and at the posttest it reached 12.03. Whereas in the control class the average value at the pretest was 7.95 and at the posttest it was 9.80. Furthermore, the acquisition of the data is processed using descriptive statistical tests. Distributed data needs to be established as proof to provide normal certainty or not a data. The normality test uses the Kolmogorov-Smirnov method with the help of SPSS 20 .

The testing criteria are if the significance value is > 0.05 then the data is normally distributed, conversely if the significance value is $<0.05$ then the data is not normally distributed. The results of the analysis of the normality test of the pretest and posttest students' critical thinking skills in the experimental class and the control class are presented in the following table 1:

Table 1. Results of Analysis of Pretest and Posttest Data Normality Test

\begin{tabular}{|c|c|c|c|c|c|c|c|}
\multicolumn{1}{|c|}{ Tests of Normality } \\
\hline \multirow{2}{*}{} & Class & \multicolumn{2}{|c|}{ Kolmogorov-Smirnov } & \multicolumn{2}{|c|}{ Shapiro-Wilk } \\
\cline { 3 - 8 } & Statistic & df & Sig. & Statistic & df & Sig. \\
\hline \multirow{2}{*}{$\begin{array}{c}\text { Critical } \\
\text { Pretest } \\
\text { Value }\end{array}$} & Experiment & .185 & 60 & .000 & .941 & 60 & .006 \\
\cline { 2 - 8 } & Control & .174 & 60 & .000 & .944 & 60 & .008 \\
\hline \multirow{2}{*}{$\begin{array}{c}\text { Critical } \\
\text { Posttest } \\
\text { Value }\end{array}$} & Experiment & .142 & 60 & .004 & .953 & 60 & .021 \\
\cline { 2 - 8 } & Control & .164 & 60 & .000 & .962 & 60 & .061 \\
\hline
\end{tabular}

a. Lilliefors Significance Correction

Table 1. shows that the pretest and posttest data of students' critical thinking skills in the experimental and control classes have a significance value of $<0.05$, which means the data are not normally distributed, so non-parametric statistical tests need to be done using the Mann-Whitney $U$ test. to find out the level of homogeneity (similarity of abilities) through pretest and posttest experimental class and control in students' critical thinking abilities. Furthermore, this test is used to prove the hypothesis that has been proposed in this study.

Basic decision making.

1. If the Asymp value is Sig $<0.05$, then the hypothesis is accepted.
2. If the Asymp value is $\mathrm{Sig}>0.05$, the hypothesis is rejected.

Hypothesis: "There are differences in critical thinking skills of students who get the Controversial Issues learning model in the experimental class with students who get conventional learning in the control class".

The results of the Mann-Whitney test data prettest students' critical thinking skills in the experimental class and control class are presented in Table 2. The following:

Table 2. Mann-Whitney U test results Posttest data . Test Statistics ${ }^{\mathrm{a}}$

\begin{tabular}{|l|r|}
\hline & Critical Pretest Value \\
\hline Mann-Whitney U & 1681.500 \\
Wilcoxon W & 3511.500 \\
Z & -.633 \\
Asymp. Sig. (2-tailed) & .527 \\
\hline
\end{tabular}

a. Grouping Variable: Kelas

Based on Table 2. It is known that Asymp. Sig. (2-tailed) of $0.527>0.05$, which means that there is no difference in the initial ability of students in the two classes namely the experimental class and the control class.

The results of the Mann-Whitney test analysis of posttest data on students' critical thinking skills in the experimental class and control class are presented in Table 2. The following:

Table 3. Mann-Whitney U test results Posttest data

\section{Test Statistics ${ }^{\text {a }}$}

\begin{tabular}{|l|r|}
\hline & Critical Posttest Value \\
\hline Mann-Whitney U & 607.000 \\
Wilcoxon W & 2437.000 \\
Z & -6.339 \\
Asymp. Sig. (2-tailed) & .000 \\
\hline
\end{tabular}

a. Grouping Variable: Kelas

Based on Table 3. It is known that Asymp. Sig. (2-tailed) of $0,000<0,05$, which means that the hypothesis is accepted. Thus it can be concluded that there are differences in critical thinking skills of students who obtain the Controversial Issues learning model in the experimental class with students who obtain conventional learning in the control class. Because there are significant differences, it can be said that there is the influence of the use of the Controversial Issues learning model on critical thinking skills of grade IV elementary school students in social studies learning. 
In this study, the variables analyzed were the effectiveness of using the Controversial Issues learning model on students' critical thinking abilities. So using a measuring instrument in the form of a written test. The critical thinking indicators that are measured in this study include; 1) provide elementary clarification, 2) build basic skills (basic support), 3) conclude (interence), 4) make further explanations (advanced clarification), 5) regulate strategies and tactics (strategies tactics).

Based on the results of the analysis of the research that has been done obtained data on the experimental class the average value achieved at pretest was 7.83 and at the time of posttest it reached 12.03. Whereas in the control class the average value at the pretest was 7.95 and at the posttest it was 9.80. From the results of the pretest and posttest data it can be observed that there was an increase in the posttest value of the pretest from the experimental class and the control class.

Proof that there are differences in the critical thinking skills of students between the experimental classes who apply the Controversial Issues learning model and the control class that applies conventional learning can be seen in the Mann-Whitney test results. This test is carried out because in the normality test the data turns out there are abnormal data so that this test is carried out. The results of the Mann-Whitney data test pretest the students' critical thinking skills obtained by the Asymp value. Sig. (2-tailed) $=0.527$, which means the value of Asymp. Sig. (2-tailed) 0.527>0.05 In the test interpreting the pretest data of the experimental class and the control class proved no difference. This proves that the results of the pretest are good. It is said to be good because in a study that will later compare between samples, it will get good results if the sample does not have far different abilities.

The statement is supported by Sugiyono [13] which explains that the pretest results are good if the value of the experimental group is not significantly different from the control group. So that it shows that there is no difference in students' initial abilities in the experimental class and the control class. After that, the Mann-Whitney test was performed on the posttest data between the experimental class and the control class. The data interprets that there are differences in students' critical thinking skills between the experimental class and the control class. The MannWhitney test results show the value of Asymp. Sig. (2tailed $=0,000$ which means the value of Asymp. Sig. (2-tailed) $0,000<0.05$. Then the hypothesis is accepted, so that it can be stated that there is a significant difference in students' critical thinking skills between the experimental class students who put forward the Controversial Issues learning model with the control class that applies conventional learning.

Based on the results of the explanation above, this is in accordance with what was stated by Suryanto
[9] that the Controversial Issues learning model can train students' critical thinking skills, because it allows students different understanding and views on an issue. Differences in views among students, will provide insight and instill awareness of the differences in life, so that eventually they will have democratic attitudes in every aspect of their lives in accordance with the reality of life in a pluralistic society.

In Desmita's research [14] learning strategies controversial issues can lead to cooperation between groups, dare to express opinions, arouse one's thinking skills, and improve student learning outcomes. evoke skills. Generating thinking skills is a forerunner in a person to master critical thinking skills, namely in making deductions and considering the results of the instruction. The depiction that has been stated is supporting evidence that controversial issues learning models can train students' critical thinking skills.

Wiriaatmadja (Faqih [15]) explains that the advantage of using controversial issue learning is training students' academic skills to make hypotheses, gather evidence, analyze data, and present the results of inquiry; train students to face complex social life with communication skills, instill a sense of empathy, influence others, be tolerant, work together, and others. Because the issues discussed are useful for studying stady cases by understanding the use of concepts, generalizations, and theories of social sciences. These skills are in line with the theory described by Dewey, J. (in Sihotang [16]) which suggests that critical thinking is an active, continuous and careful consideration of a belief or form of knowledge that is taken for granted by including reason- reasons that support and rational conclusions.

The success in mastering students' critical thinking skills using the Controversial Issues learning model is in line with what was revealed by Indrawati [17] that teaching with controversial issues can develop new opinions that are better so that high-level thinking processes occur that are analyzing, synthesizing, and evaluating. Explanation is in accordance with the results of research that has been obtained and in harmony with the theory described by DN Perkins (in Hassoubah, [18]) said that critical thinking means: a) Aiming to achieve a critical assessment of what we will receive or what we will do it with logical reasons, b) use assessment standards as a result of critical thinking in making decisions, c) implement a variety of structured strategies and provide reasons to determine and apply these standards, d) seek and collect reliable information to be used as evidence who can support an assessment. From this explanation, it can be concluded that critical thinking is analytical thinking by finding and gathering reliable information to draw conclusions in solving a problem. In critical thinking provides an acceptable belief in the assumption because the evidence used can support an assessment. 
Etin [19] further strengthens the above statements by revealing that learning controversial issues can increase motivation and student learning activeness, can arouse students' thinking abilities. Through different opinions students can develop new and better opinions. Increased learning motivation and active learning will certainly influence the learning outcomes that have been used as learning objectives, namely the achievement of students' critical thinking skills.

Through the results of the research and theory above, the Mann-Whitney test has proven that there are significant differences in students' critical thinking skills between the experimental classes that apply controversial issues learning models with the control class that apply conventional learning. The difference illustrates overall that the sample between the experimental class and the control class at the beginning of learning has the same critical thinking skills, but after being given different treatments on both, the experimental class with controversial issues and control class with conventional learning turned out to acquire thinking skills different critical. In the experimental class students' thinking skills are far better when compared to the control class.

\section{CONCLUSION}

Based on the results of research and discussion on the research entitled "The Effectiveness of Using Controversial Issues (CI) Learning Models on Critical Thinking Ability" it can be concluded that there are differences in critical thinking skills of students who learn using controversial issues in the experimental class with students who obtain conventional learning. These differences lead to the critical thinking ability of students in the experimental class is much better when compared to the control class, the success of applying the controversial issue model can be seen from the ability of students to provide simple explanations, build basic skills, ability to conclude, make further explanations and set strategies and tactics in learning.

\section{REFERENCES}

[1] Kaddoura, M. 2009. New Graduate Nurses" Perception of Critical Thinking Development in Critical Care Nursing Training Programs. Dissertation Health Professions Education

[2] Hughes, C. 2014. Theory of Knowledge aims, objectives and assessment criteria: An analysis of critical thinking descriptors. Journal of Research in International Education, Vol. 13(1) 30: sagepub.co.uk/journalspermissions.nav.

[3] Kettler, T. 2014. Critical Thinking Skills Among Elementary School Students: Comparing
Identified Gifted and General Education Student Performance. Gifted Child Quarterly 2014, Vol. 58(2) 127-136: sagepub.com/journalsPermiss ions.nav.

[4] Somantri, M. 2014. Efektivitas penggunaan Model pembelajaran Inkuiri sosial dalam mengembangkan kemampuan berpikir kritis dan komunikasi sosial anak pada mata pelajaran ilmu pengetahuan sosial.(Tesis). Sekolah Pascasarjana, Universitas Pendidikan Indonesia, Bandung.

[5] Takidin. 2010. Dampak pembelajaran berbasis masalah terhadap peningkatan penguasaan konsep IPS dan kemampuan memecahkan masalah sosial siswa.(Tesis). Sekolah Pascasarjana, Universitas Pendidikan Indonesia, Bandung.

[6] Gunawan, R. 2013. Pendidikan IPS, filosofi, konsep, dan aplikasi. Bandung: Alfabeta.

[7] Mulyati, Cici. 2012. Pembelajaran PKn Dengan Menerapkan Pendekatan Kontekstual (CTL) Melalui Model Pembelajaran Controversial Issues Untuk Meningkatkan Motivasi Belajar Siswa. Skripsi Sarjana pada FPIPS UPI Bandung: Tidak Diterbitkan.

[8] Komalasari. 2013. Pembelajaran Kontekstual: Konsep dan aplikasi. Bandung: PT. Refika Aditama.

[9] Suryanto dkk. 2018. Analisis Sintakmatik Permainan Simulasi Berlatar Isu-Isu Kontroversial Untuk Meningkatkan Keterampilan Menganalisis Informasi Pada Siswa SMA. Efektor Vol 5 No 1 Tahun 2018: 1-7. http://ojs.unpkediri.ac.id/index.php/efektore/article/view/11946

[10] Sugiyono. 2013. Model Penelitian Kombinasi (Mixed Methods). Bandung: Alfabeta.

[11] Ruseffendi. E.T .2006. Dasar-dasar penelitian pendidikan dan bidang non eksakta lainnya. Semarang: IKIP Press.

[12] Creswell, JW. 2014. Research design, pendekatan kualitatif, kuantitatif, dan mixed. Yogyakarta: Pustaka Pelajar.

[14] Desmita, 2013. Peningkatkan Motivasi Belajar Siswa Melalui Strategi Pembelajaran Isu Kontroversial Pada Mata Pelajaran Ilmu Pengetahuan Sosial Materi Permasalahan Sosial di Kelas IV Sekolah Dasar Negeri 002 Lubuk Ambacang Kecamatan Hulu Kuantan Kabupaten Kuantan Singingi. Skripsi sarjana pada Universitas Islam Negeri Sultan Syarif Kasim Riau, Pekanbaru (tidak diterbitkan).

[15] Faqih, Warid Fadillah, dkk. 2014. Upaya Peningkatan Aktivitas dan Hasil Belajar Mata Pelajaran Sejarah Melalui Penerapan Pembelajaran Isu Kontroversial. http://repository. unej.ac.id/handle/123456789/64184. (Diakses 12 November 2018) 
[16] Sihotang, K., dkk. 2012. Critical thinking, membangun pemikiran logis. Jakarta: Pustaka Sinar Harapan.

[17] Indrawati, Henny. 2011. Meningkatkan Keterampilan Berpikir Kritis Mahasiswa Melalui Implementasi Model pembelajaran Controversial Issues Pada Mata Kuliah Ekonomi Sumberdaya Manusia Dan Alam. PEKBIS (Jurnal Pendidikan Ekonomi Dan Bisnis).Vol 4, No 01 (2011): 63-70. https://ejournal.unri.ac.id/index.php/JPEB/article/ view/430

[18] Hassoubah, Z.I. 2008. Developing creative and critical thingking skills (terjemahan). Bandung: Nuansa.

[19] Etin, Solihatin. 2012. Strategi Pembelajaran $P P K N$. Jakarta: Bumi Aksara.

[13] Sugiyono. 2008. Metode penelitian kuantitatif, kualitatif dan $R \& D$, Bandung: Penerbit Alfabeta. 